\title{
Konflik Keinginan Daging dalam Diri Paulus: Sebuah Analisis Roma 7:13-26
}

\author{
Benyamin, M.Pd.K ${ }^{1 *}$ \\ ${ }^{1}$ Prodi Pendidikan Agama Kristen, STT Anugerah Sinagoge Medan \\ *marbun.benyamin@gmail.com
}

\begin{abstract}
Abstrak
Tujuan studi ini untuk membuktikan keberadaan Paulus dalam Roma 7:13-25. Keberadaan Paulus merupakan suatu topik yang diperdebatkan sepanjang sejarah gereja yang menghasilkan beragam pendapat. Dalam perjalanannya sampai sekarang belum ada kesepakatan mengenai keberadaan Paulus tersebut. Perdebatan mengenai keberadaan Paulus menghasilkan empat pandangan dasar yaitu pertama Paulus Sendiri, kedua Adam, ketiga Orang Israel di bawah Taurat, keempat Orang-orang Kristen, dalam penelitian ini penulis ingin mendalami kemungkinan yang paling tepat yaitu pandangan yang pertama. Namun dalam pendapat yang pertama ini juga ada dua pandangan, apakah Paulus yang berjuang menghadapi keinginan daging tersebut ketika ia sebelum percaya atau sesudah percaya? Dalam tulisan ini penulis menggunakan analisis eksegesis untuk membuktikan keberadaan Paulus sesuai dengan konteks dari Roma 7:13-25.
\end{abstract}

Kata kunci: eksegesis, penafsiran, sejarah, gereja, dosa, daging

\begin{abstract}
The purpose of this study is to prove Paul's existence based o Romans 7: 13-25. Paul's existence is a contentious topic throughout the history of church which has resulted in a variety of opinions. In his journey, there has been no agreement on Paul's existence. The debate about Paul's existence produced four basic views, namely, first Paul Himself, the second Adam, the three Israelites under the Torah, the four Christians. In this study, the author wanted to explore the most appropriate possibility of main view. However, in this first opinion there are also two views, namely, whether Paul struggling with the desires of the flesh when he believed or after believing? In this paper, author uses exegesis analysis to prove Paul's existence according to the context of Romans 7:13-25.
\end{abstract}

Keywords: exegesis, interpretation, history, church, sin, flesh

\section{PENDAHULUAN}

Pemikir terbesar dalam Perjanjian Baru yang menafsirkan makna pribadi dan pekerjaan Yesus adalah orang Farisi yang telah bertobat, yaitu Paulus (Ladd, 2002). Paulus adalah rasul yang sangat terkenal dan banyak tulisannya yang diperdebatkan oleh para teolog, salah satu masalah yang diperdebatkan yaitu mengenai keberadaan dirinya di dalam Roma 7:13-26. Brevard S. Childs mengatakan:

"A somewhat akin, but more complex profiling of a representative addressee occours in Rom 7. The problem has long been debated as to whether the first-person subject-some claimed it to be directly autobiographical-should be set in a chronological sequence before or after the Christian conversion (Childs, 1985)." 
Menurut Dunn (1985) ada tiga pandangan yang mewakili seluruh perdebatan mengenai pengalaman Paulus di dalam Roma 7:13-26 ini, yaitu:

“(1) Perikop ini merupakan catatan otobiografis tentang pengalaman Paulus sebelum bertobat; (2) perikop ini bukan otobiografis, tetapi melukiskan umat manusia secara umum, atau kaum Yahudi secara khusus, di luar Kristus dan di bawah Taurat; (3) Paulus sedang melukiskan pengalaman Kristennya."

Masih ada beberapa pandangan yang belum terwakili oleh pandangan umum di atas, hal ini dikarenakan banyaknya pandangan yang telah diterima dan di sepanjang sejarah gereja hal ini menjadi perdebatan oleh Bapak-bapak gereja yang dimulai dari Agustinus. Sebagian besar tokoh gereja mula-mula berpendapat bahwa ayat-ayat tersebut mendeskripsikan orang yang belum bertobat. Pendapat Agustinus ini kemudian mengalami perubahan karena pertentangannya dengan Pelagius, sehingga Agustinus mengubah opininya dan memutuskan bahwa orang yang digambarkan dalam ayat-ayat itu adalah orang Kristen (Moo, 1996:444). Berikut ini adalah pernyataan-pernyataan para teolog mengenai Roma 7:13-26. Apakah ketidakharmonisan yang digambarkan dalam Roma pasal 7:13 dan seterusnya terjadi dalam diri orang Kristen, ataukah Paulus mau memperlihatkan ketidakmampuan dalam melakukan hukum Allah khususnya orang yang berada di luar Kristus dan kuasa Roh Kudus (Ridderbos, 2008:124).

Jelaslah bahwa perdebatan yang berkepanjangan ini layak untuk diteliti dan dipecahkan masalahnya, karena kepastian yang tepat mengenai pengalaman Paulus ini akan mempengaruhi konsep teologia seseorang mengenai teologia Paulus dan pasti hal ini merupakan suatu berita yang krusial bagi kekristenan, karena orang yang sudah menang atas dosa malah masih terus-menerus dikuasai dosa.

Apakah pergumulan Paulus dalam Roma 7:13-26 itu merupakan pergumulan antara dosa dan daging? Apakah gambaran yang Paulus berikan tersebut merupakan suatu pengalaman yang terjadi pada orang yang di luar Kristus atau orang yang sudah berada di dalam Kristus, serta apa relevansi pergumulan Paulus ini dalam kehidupan orang percaya?

Tujuan dari penulisan artikel ini adalah untuk mengkaji dua pandangan mengenai keberadaan "ego" (Moo, 1996:445-446). Kesalahan dalam menginterpretasikan pengalaman Paulus ini dapat membuat orang percaya kehilangan kompas yang dapat membawa orang percaya untuk memahami teologia Paulus secara komprehensif terutama mengenai kehidupan sebagai orang percaya dalam mengalahkan keinginan dagingnya atau dengan kata lain pengudusan hidup. 


\section{Empat Pandangan Dasar}

Di dalam Roma 7 sangatlah dimungkinkan bahwa kata "aku" digunakan oleh Paulus secara literal dan otobiografis. Namun, banyak para ahli yang mengajukan pertanyaan apakah "aku" memenuhi sebuah fungsi retoris dan oleh karenanya mengasumsikan sebuah pemahaman bersifat kiasan (Lambrecht, 1974:59). (Numerous readers, however, rise the question whether that "I" fulfills a rhetorical function and therefore assumes a figurative sense. Jika demikian, maka masih ada lebih dari satu kemungkinan. Adapun kemungkinan tersebut dapat dibagi menjadi empat pandangan.

\section{Paulus Sendiri}

Sebuah solusi yang jelas dan mudah berpendapat bahwa Paulus tidak mengacu pada orang lain melainkan dirinya sendiri. Menurut pandangan tersebut, Paulus sedang menuliskan bagian dari otobiografinya dalam Roma 7. Ia digambarkan sebagai seorang anak laki-laki yang masih dibawah umur, belum mengenal hukum, hidup di luar hukum itu, dosa di dalam dirinya dalam keadaan mati (tak berdaya). Ketika memasuki ambang usia pubertas, ia adalah sasaran dari hukum Taurat. Paulus menjadi anak dari hukum Taurat. Dosa yang sedang mengintip (tersembunyi) memanfaatkan perintah-perintah tersebut untuk membujuk atau memperdayakan dan membunuhnya.

Berdasarkan teks tersebut, Paulus memberikan informasi mengenai masa atau kurun waktu sebelum pertobatannya. Sebagai seorang Farisi, ia harus bertarung dengan sebuah pergumulan yang tersembunyi namun tragis, dan akhirnya ia akan binasa melalui sebuah konflik yang terus menerus antara kehendaknya akan berbuat yang baik dan perbuatannya yang riil. Adanya fakta dalam mengenal dan menyetujui apa yang baik, dan disertai dengan pengalaman pribadi mengenai ketidakberdayaan untuk melakukan apa yang baik, hal tersebut akan membawanya kepada ambang batas kehancuran dan keputusasaan. Jadi, di dalam rencana Allah, pertobatan Paulus telah dipersiapkan dalam cara yang negatif. Pengetahuan akan hukum Taurat dan dominasi (kekuasaan) dosa, mendorong dirinya akan kebutuhan bagi suatu pelepasan.

Opini dari Robert H. Gundry lebih spesifik mengacu pada perintah, "Janganlah mengingini!" (perintah kesepuluh dari sepuluh perintah). Paulus secara spesifik mengacu pada 'keinginan nafsu seksual' yang timbul selama masa pubertas. (Paul more specifically refers to sexual desire which awaknes during puberty). Sebagai seorang yang tidak menikah, Paulus harus berjuang melawan keinginan atau nafsu tersebut tanpa harapan berhasil mengatasinya (Gundry, 1980:234). (As an unmarried person Paul must have fought against this desire without hope of succes). Menurut Gundry, Paulus 
menyerah kalah kepada godaan dan dosa yang dalam. Di dalam Filipi 3:4-6 dan Gal. 1:13-14, Paulus membanggakan aktivitas-aktivitas religiusnya yang tidak kontradiktif dengan pandangan semacam ini. Semangat fanatisme adalah nampak dari luar dan bersifat kasat mata; namun dosa seksual Paulus bersifat tidak kasat mata. Adam

Jika "aku” dalam Roma 7:7-26 bukanlah Paulus sendiri, kiasan-kiasan mengenai kisah Kejadian memperlihatkan bahwa Paulus menunjuk kepada Adam, meskipun kontradiktif dengan Roma 5:12-21 dinama Adam tidak disebutkan dalam perikop tersebut (Lambrecht, 1974). Sebuah argumentasi dari Stanislas Lyonnet: "sebenarnya...data tidaklah hilang dimana membuktikan bahwa Paulus berpikir mengenai Adam, dan mengenai kisah Kejadian yang dideskripsikan terutama dalam kehidupannya yang akrab dengan Allah, kemudian mengenai dosanya dan tindak tanduknya dimana ular mempergunakan perintah tersebut untuk membangkitkan keinginan dari perempuan (Hawa), dan akhirnya kematian dimana nenek moyang kita dahulu menderita sebagai sebuah penghukuman bagi ketidak taatan mereka.

Dalam kedua kasus tersebut (Kejadian 2-3 dan Roma 7) memiliki oknum yang sama: pertama, seorang manusia, suatu jenis dari ras manusia dan di dalam ras tersebut manusia seutuhnya tersebut disebut sebagai seorang ego (aku); kedua, sebuah perintah tertentu, $\varepsilon v \tau \mathrm{o} \lambda \varepsilon$ (entole) dalam bentuk tunggal dalam tulisan Paulus sebagaimana juga di dalam kitab Kejadian; ketiga, dosa yang dipersonifikasikan, $\eta \dot{\alpha} \mu \alpha \rho \tau \iota \alpha$ (he hamartia) yang memainkan sebuah peranan yang analog dengan ular dalam kitab Kejadian dan iblis dalam perikop kebijaksanaan yang telah menginspirasi Paulus dalam Roma 5. Karena dalam Roma 5:12, ia menegaskan bahwa kematian datang kedalam dunia melalui dosa.

Selanjutnya Lyonnet membuat perbandingan cara (jalan masuk) dimana ular dalam kitab Kejadian dan dosa di dalam Roma 7 mempergunakan larangan tersebut yang ditujukan untuk memberikan kehidupan, namun sebenarnya membawa kepada kematian (Lambrecht, 1974). Ia menyimpulkan bahwa Roma 7:13-23 mendeskripsikan kondisi Adam setelah kejatuhan. Adanya dampak dari kisah Kejadian 2-3 terhadap Roma 5 dan 7 tidak dapat disangkali. Namun, sulit untuk mengakui bahwa "aku" dari Roma 7:7-26 harus diidentifikasikan dengan Adam (ataupun dengan setiap orang). Pernyataan-pernyataan spesifik dan kiasan-kiasan dalam surat rasul Paulus jelas-jelas memperhatikan hal-hal yang berkaitan dengan hukum Taurat dan orang Yahudi serta problemnya. Konteks secara keseluruhan itu sendiri sulit untuk dipahami bahwa Paulus 
sedang menulis dalam suatu kurun waktu yang tidak terbatas dan mengacu pada pengalaman-pengalaman dan kondisi-kondisi manusia secara universal.

\section{Orang Israel di Bawah Taurat}

Pada bagian akhir dari Roma 7:7, perintah kesepuluh dari sepuluh perintah Allah disebutkan. Apakah hal ini tidak mengindikasikan bahwa Paulus sedang memikirkan tentang proklamasi mengenai hukum Taurat di atas gunung Sinai, terutama sejak tradisi Yahudi memandang "Jangan kamu mengingini!" sebagai kesimpulan dari seluruh sepuluh perintah Allah? Kemudian, ayat 8b (tanpa hukum Taurat dosa mati) mengingatkan kita pada Roma 5:12-14 dimana Paulus merefleksikan pada kurun waktu dari Adam sampai Musa.

Dalam kurun waktu itu ada dosa, namun bukanlah merupakan pelanggaran yang riil dari perintah-perintah tersebut, karena sepuluh perintah Allah belum diproklamasikan. Jelas bahwa dari semua data tersebut, kesimpulan yang didapat bahwa Roma 7:9b-11 juga mengacu pada proklamasi di gunung Sinai, sebagaimana perintah dari ayat 7. Para komentator yang mempertahankan pandangan yang ketiga ini tidaklah menolak bahwa Paulus menggambarkan tipu muslihat dosa pada pola dari apa yang dilakukan oleh ular dalam kitab Kejadian dan iblis dalam wisdom, namun "aku" mewakili orang Israel (Lambrecht, 1974). Dalam Roma 7:7-11 Paulus mengisahkan apa yang diperbuat oleh dosa dengan hukum Taurat setelah diberikan di atas gunung Sinai. Dengan menyalahgunakan hukum Taurat, dosa menipu atau memperdaya orang Israel.

\section{Orang-orang Kristen}

Orang percaya hidup di bawah kasih karunia (Rm 6:14), ia mati bagi hukum Taurat dan melayani dalam keadaan baru menurut Roh (Rm 7:6). Namun, orang Kristen masih hidup di dalam dunia. Kelanjutan dari pernyataan-pernyataan yang sangat jelas menunjukkan Paulus memilki banyak kalimat perintah dan peringatan. Sebagai contoh: Galatia 5:16-18, "maksudku ialah: hiduplah oleh Roh, maka kamu tidak akan menuruti keinginan daging. Sebab keinginan daging berlawanan dengan keinginan Roh dan keinginan Roh berlawanan dengan keinginan daging, karena keduanya bertentangan. Perikop ini merupakan sebuah paralelisme dari perikop dalam Roma 7. Galatia 5:17 secara khusus mengingatkan kita pada konflik yang Paulus paparkan panjang lebar dalam Roma 7.

Banyak komentator yang menganut penjelasan Agustinus (yang juga dianut Aquinas) dan sepakat dengan Luther beserta referensinya dalam hal ini. Mereka mengaitkan Roma 7:7-26 dengan pergumulan-pergumulan yang terus memberi pengaruh 
pada setiap orang Kristen. Patut diingat bahwa fakta yang terdapat dalam Roma 7:13 dan seterusnya memakai kata kerja dalam bentuk masa kini (present tense). Dalam opini mereka, Roma 7:25 memberi kesaksian terhadap suatu pepatah yang terkenal simul iustus et peccator (pada saat yang bersamaan seorang yang benar dan sekaligus seorang pendosa).

Tokoh-tokoh seperti, J.D.G Dunn, R.Y.K Fung, John Murray, C.K.Barrett, serta C.E.B Cranfield tetap mempertahankan pandangan keempat ini. Mereka berargumentasi bahwa setelah pembenaran dan pembaptisan, tekanan-tekanan yang menyakitkan antara roh dan daging masih tetap berlangsung. Menurut pandangan mereka, pernyataan positif yang berkaitan dengan "aku"; batiniah dan pikiran, semuanya mengacu pada kondisi orang yang bertobat (Cranfield, 1979). Sebagaimana halnya dengan para orang kudus di zaman Perjanjian Lama, begitu pula dengan rasul Paulus yang sudah bertobat menyadari akan keberdosaannya. Bahkan setelah pembaptisan, dosa dan kasih karunia saling berjuang di dalam diri orang yang sama. Apa yang digambarkan dalam Roma 8 , dalam kehidupan seorang Kristen, tidak muncul setelah Roma 7, dua situasi yang muncul secara serentak (bersama-sama) di dalam diri orang Kristen yang sama. Kontradiksi antara Roma 7 dan 8, sebuah kontradiksi antara "belum" dan "sudah," suatu karakteristik eksistensi orang Kristen sampai akhir zaman.

Kadang-kadang interpretasi semacam ini lebih fleksibel melalui kualifikasi bahwa pergumulan hidup akan menjadi berat pada awal pertobatan ataupun melalui pengakuan bahwa suatu konflik seperti yang dideskripsikan dalam Roma 7 bukanlah suatu situasi yang normal dari orang Kristen. Memang tidak diragukan bahwa di dalam Galatia 5:16-18 Paulus menunjukkan surat tersebut kepada para pengikutnya (orang Kristen), dan peringatan-peringatannya yang dimaksudkan untuk pergumulan mereka yang terus berlangsung. Dalam perikop tersebut, Roh yang memberikan pertolongan yang efektif yang akan membawa kepada suatu signifikansi yang besar.

Perdebatan Identitas “aku”

Dalam ay 14-25, Paulus terus berbicara dalam orang pertama tunggal, dengan meninggalkan bentuk lampau dan beralih ke bentuk masa kini. Sebelum masuk kedalam teks, hal yang patut diketengahkan di sini adalah mengenai siapakah yang dimaksud dengan $a k u$ dalam konteks ini? Namun, sebelum masuk ke bagian selanjutnya perlu diketengahkan di sini bahwa ada dua pandangan tentang penerimaan dari "aku", kedua pandangan ini merupakan pandangan yang banyak diterima secara umum. Adapun dua pandangan itu antara lain: 


\section{Di Luar Kristus}

Pelagius dan kaum Armenian berpendapat bahwa perikop tersebut menggambarkan seorang yang tidak dapat dipulihkan atau seorang non-Kristen.

\section{Dasar Argumentasi}

Argumentasi yang mendukung "aku" sebagai Paulus yang belum bertobat (Moo, 1996): (1) Relasi yang kuat antara "aku” dan "daging” (ay.14,18,25) mendukung asumsi bahwa Paulus sedang menjelaskan keadaan orang yang belum bertobat (bnd 7:5); (2) "Aku" dalam bagian ini berjuang dengan usaha sendiri (terutama ay. 25) tanpa bantuan dari Roh Kudus; (3) "Aku” berada di bawah kuasa dosa (ay.14b), sedangkan orang percaya telah dibebaskan dari situasi tersebut $(6: 2,6,11,18-22)$; (4) Perjuangan yang gagal di ayat 15-20 membuat "aku" menjadi tawanan hukum dosa (ay.23), padahal orang percaya sudah dibebaskan dari hukum dosa (8:2); (5) Orang percaya memang masih bergumul dengan dosa $(6: 12-13 ; 13: 12-14$; Gal 5:17), tetapi yang digambarkan di Roma 7:13-26 bukan hanya pergumulan, sebaliknya sebuah kekalahan dari dosa; (6) "Aku" di sini bergumul dengan kebutuhan untuk memenuhi kebutuhan Taurat, padahal Paulus sudah mengajarkan bahwa orang percaya bebas dari tuntutan Taurat $(6: 14 ; 7: 4-$ $6)$.

\section{Di dalam Kristus}

Pandangan yang mengatakan bahwa bagian ini menunjuk pada hidup orang yang sudah percaya didukung oleh:

\section{Dasar Argumentasi}

Argumentasi yang mendukung "aku" sebagai Paulus yang sudah bertobat (Moo, 1996), yaitu: (1)Sebagaimana ayat 7-12, “aku" disini pasti merujuk pada Paulus. Pergantian tense dari bentuk lampau (ay.7-12) ke bentuk kekinian (present) di ayat 1325 menunjukkan bahwa Paulus sedang memaparkan pengalamannya sebagai orang yang percaya; (2) Orang yang belum bertobat tidak mencari Allah (3:11) dan tidak tunduk pada hukum Allah (8:7), sedangkan "aku" mencintai hukum Allah (ay.22). berusaha untuk menaatinya (ay.15-20) dan melayaninya (ay.25); (3) Pikiran orang yang belum bertobat biasanya digambarkan secara negatif oleh Paulus (1:28; Ef 4:17; Kol 2:18; I Tim 6:5; II Tim 3:8; Tit 2:15), sedangkan pikiran "aku" dalam konteks ini sifatnya positif (ay. 22, 25); (4) Hanya orang percaya yang memiliki 'manusia batiniah' (ay.22). Paulus juga menggunakan istilah ini di II Korintus 4:16 dan Efesus 3:16 untuk orang percaya; (5) Konklusi bagian ini (ay.25b) setelah penyebutan pelepasan oleh Tuhan 
Yesus (ay.25a) tetap menyebut perbedaan antara akal budi (melayani hukum Allah) dan tubuh insani (melayani hukum dosa).

Dalam penelitian ini penulis lebih setuju dengan pendapat yang kedua, yaitu Paulus yang sudah percaya kepada Kristus, sama dengan Methodius, Agustinus, Thomas Aquinas, Luther, dan Calvin, serta sejumlah theolog modern lainnya, yang sepakat dengan pandangan bahwa orang yang dideskripsikan dalam perikop tersebut adalah seorang Kristen. Oleh sebab itu, penulis juga mengadopsi pandangan dari bapak-bapak Gereja tersebut dalam penggalian Roma pasal 7 ini.

\section{EKSPOSISI ROMA 7: 13-25}

\section{Peranan Hukum Taurat}

Dalam ayat 13 Paulus hendak menjernihkan pandangan dalam kaitan antara dosa dan hukum. Jika sebelumnya ia menyebut hukum adalah kudus, benar dan baik (ayat 12), maka muncul suatu pertayaan retorikal: "apakah yang baik itu menjadi kematian bagiku?" jawabannya tegas: "tidak!" Ini jelas merupakan pembelaan Paulus terhadap hukum. Pertanyaan di dalam ayat ini merupakan antisipasi terhadap kemungkinan kesalahpahaman tentang pernyataan Paulus di ayat 7-12. Pertanyaan ini sebenarnya mirip dengan isu di ayat 7-12, namun perbedaannya terletak pada dua hal: (1) Ayat 7-12 lebih terfokus pada aspek eksternal antara dosa dan Taurat, sedangkan ayat 13-26 pada aspek internal antara dosa dan kedagingan manusia. (2) ayat 13-25 relatif lebih detail daripada penjelasan di ayat 7-12.

Inilah prinsip dari dosa. Dosa menggunakan hukum sebagai "sesuatu yang baik" sebagai alat atau instrument yang melaluinya dapat menghasilkan kematian bagi seseorang (Witmer, 1988). Hukum diberikan supaya orang dapat memiliki pengetahuan tentang dosa (Chamblin,1993), artinya dia mengetahui bahwa apa yang dilakukannya adalah dosa dan supaya dosa itu terlihat nyata sebagai dosa.

Leon Morris mengatakan bahwa tanpa hukum kita tidak dapat menyadari bahwa dosa itu adalah sesuatu yang jahat dan orang percaya tidak dapat melihatnya sebagai suatu pelanggaran terhadap hukum Allah (Morris, 1988:284). Kebenarannya adalah bahwa dosa telah mengeksploitasi hal-hal yang baik dalam upaya untuk menyempurnakan kematian manusia. Dalam bagian ini Paulus ingin memberitahukan peranan dari hukum Taurat itu yaitu: Pertama, memberikan kepada manusia suatu pengetahuan mengenai dosa bukan semata-mata merupakan esensi dari suatu gagasan mengenai dosa, melainkan dosa sebagai sebuah realita yang konkret, yang memiliki sifat 
dinamis di dalam dosa itu sendiri, suatu roh pemberontakan melawan Allah, dan terhadap ketidaktaatan terhadap perintah-perintah-Nya (Rm 7: 7, 13; Rm 3:20).

Kedua, suatu cara di mana hukum Taurat memberikan pengetahuan akan dosa tersebut dengan mendeklarasikan larangan-larangan Allah dan perintah-perintah-Nya, dan melalui larangan-larangan-Nya tersebut mendorong dosa kedalam pemberontakan yang aktif dan kemudian membuat manusia waspada terhadap pelanggaran-pelanggaran yang spesifik serta kelemahan-kelemahan dalam motif dan perbuatan ke dalam dosa yang mendorong hal-hal tersebut $(\operatorname{Rm} 7: 8,19,23)$. Ketiga, hukum Taurat memberikan ketidakmampuan kepada siapapun untuk memperlihatkan apa yang baik seperti apa yang dijabarkan, dan juga ketidakmampuan untuk membebaskan manusia dari kuasa dosa (Rm 7:9-11, 22-24).

Hal ini disebutkan dalam ayat ini, di mana juga mengindikasikan bahwa eksploitasi dosa terhadap hukum Taurat sebenarnya mengandung dua unsur dari tujuan ilahi dalam memberikan Taurat, yaitu bahwa dosa diperlihatkan sebagai dosa, dan bahwa dengan memakai perintah tersebut, maka kebobrokan karena dosa itu semakin bertambah atau meningkat.

\section{Konflik Hidup Orang Percaya}

Dalam ayat 14 yang memberikan bukti dalam konfirmasi dari apa yang telah Paulus nyatakan dalam ayat 13 , bentuk kalimat masa lampau (past tense) menjadi bentuk kalimat sekarang (present tense), dan sebagaimana rangkaian pernyataan yang tertulis menjadi jelas, rasul Paulus memfokuskan pandangannya kepada orang-orang Kristen.

Dalam ayat 14 Paulus kembali menyatakan pembelaannya terhadap hukum. Dia mengatakan bahwa "hukum Taurat adalah rohani," "as a rule it is used of impersonal things, the Law given by God."(lazimnya peraturan itu digunakan mengenai orang tertentu, Hukum diberi oleh Allah) (Bauer,1979). Hukum diberikan melalui wahyu dan inspirasi Roh. Di sini hukum jelas dihubungkan dengan karakter kekudusan dari Roh yang dinyatakan kepada manusia bahwa hukum itu adalah ilahi (Dunn, 1985). Paulus mengkontraskan dirinya dengan hukum: "tetapi aku bersifat daging." $\Sigma \alpha \rho \kappa ı v o \varsigma$ (sarkinos) kata ini hanya empat kali muncul di dalam Perjanjian Baru. Kata ini mempunyai dua arti, pertama: daging (terdiri dari daging atau dalam daging); dan kedua: fleshly, belonging to the realm of the flesh in so far it is weak, sinful and transitory (kedagingan, keinginan daging yang bersifat keduniawian dalam kelemahan,

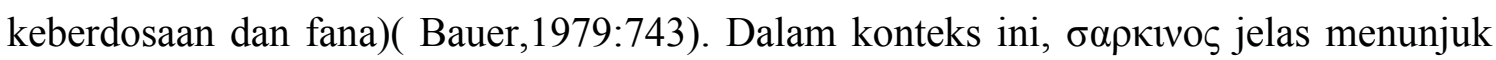


kepada arti yang kedua, yaitu yang bersifat daging. Jadi, kata daging di sini diaplikasikan kepada orang percaya (bnd. I Kor 3:1) yang menunjukkan indikasi suatu kelemahan atau ketidak sempurnaan (Wuest,1992).

Cranfield memberikan pendapatnya tentang hal ini:

We take it then that Paul is here describing the Christian as carnal and implying that even in him there remains so long as he continues to live this mortal life, that which radically opposed to God, thought chapter 8 will make it abundantly clear that he does not regard the Christian as being carnal in the sense unqualified way the natural man is carnal (Cranfield, 1975). (Kita menyatakan itu bahwa Paulus di sini sedang menjelaskan kekristenan sebagai hal yang bersifat jasmaniah dan menyatakan secara tidak langsung bahwa di dalamnya tetap berkelanjutan yaitu bahwa dia menghidupi kehidupan yang berdosa yang mana secara radikal bertentangan dengan Tuhan, pemikiran dalam pasal 8 akan membuat penjelasan itu semakin jelas bahwa dia tidak menganggap kekristenan itu sebagai cara hidup yang bersifat jasmani yang tidak memenuhi syarat sifat alami manusia adalah bersifat jasmani).

Dalam ayat 15 untuk kedua kalinya Paulus menggunakan kata sebab untuk memperjelas argumen tentang "terjual di bawah kuasa dosa." Bagian ini dapat diterjemahkan secara literal: “apa yang saya hasilkan, saya tidak setuju.” Bagian ini merupakan penjelasan subyektif yang menerangkan akibat dari sifat kedagingan dan situasi terjual dibawah dosa (ayat 14). Paulus memulai dengan pernyataan "aku tidak tahu apa yang aku lakukan." Cranfield mengartikan bagian ini dengan: "saya tidak

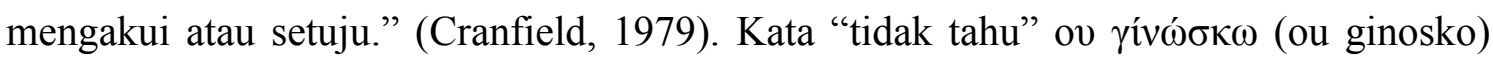
lebih tepat dipahami sebagai "tidak menyetujui" (D. J Moo, BAGD), meskipun arti umum ginosko memang "mengetahui." Arti ini juga didukung oleh anak kalimat selanjutnya.

Paulus justru melakukan apa yang ia benci, padahal keinginannya melakukan yang baik. Ada pertentangan antara "keinginan" (sifatnya positif) dan "ketidakmampuan" (sifatnya negatif). Kondisi ini membuktikan dua hal: Pertama, bahwa Taurat adalah baik. Artinya eksistensi konflik antara yang baik dan yang jahat dalam diri manusia membuktikan Taurat adalah baik (diingini oleh elemen yang baik dalam diri manusia). Kedua, bahwa dosa begitu menguasai manusia. Inti ayat 17-20 terletak pada eksistensi dosa yang menjadi penyebab ketidak mampuan manusia melakukan apa yang baik. Karena itu, jelaslah bahwa bagian ini mengambarkan pertentangan dan dalam kasus ini yang Paulus hadapi ialah dosa. Paulus mengatakan: 
"bukan apa yang aku kehendaki yang aku perbuat, tetapi yang aku benci, itulah yang aku perbuat.” Inilah problem yang dihadapi oleh setiap orang percaya.

Bentuk Present Participle inilah yang banyak dipakai secara berulangkali oleh Paulus dalam bagian ini untuk menunjukkan suatu kelanjutan dari konflik yang terus menerus melawan dosa yang ada dalam dirinya. Perkataan dari Paulus di sini bukan dimaksudkannya untuk mengelak dari tanggung jawab atas tindakannya. Jadi, di sini Paulus hendak menegaskan bahwa bukan dia yang melakukan apa yang jahat tetapi dosa yang ada dan diam di dalam dirinya yang menghasilkan apa yang Paulus benci.

Dalam ayat 18 dikatakan: "Sebab aku tahu di dalam aku sebagai manusia (NIV: sinful nature) tidak ada sesuatu yang baik." Aku yang pertama menghendaki hal-hal yang baik, sedangkan aku yang kedua menghendaki hal-hal yang tidak baik. Kata daging yang digunakan ialah $\sigma \alpha \rho \xi$ (Bauer, 1979). Cranfield mengatakan bahwa dengan kata daging di sini Paulus tidak mengartikan diri dalam pengertian "yang rendah" atau "di bawah" sebagai bagian dari manusia yang dikontraskan dengan bagian lain dari natur manusianya, tetapi itu untuk menunjukkan keseluruhan natur manusia yang telah rusak (Cranfield,1979). Dengan demikian kata daging di sini bukan berarti daging secara literal yaitu fisik atau materi dari daging tetapi menunjuk kepada natur manusia yang sudah rusak di mana berdiam prinsip dosa yang terekspresi melalui pikiran atau tubuh.

Hukum akal budi juga dikontraskan dengan daging atau dengan anggota-anggota tubuh, sehingga walaupun Paulus mempunyai kehendak untuk berbuat apa yang baik, Paulus tidak melakukannya. Dalam bagian ini dikatakan Paulus berada dalam keadaan sebagai tawanan dari hukum dosa yang berada dalam anggota-anggota tubuhnya. Bentuk kata kerja yang sama diulangi di sini yaitu $\alpha \nu \tau 1 \sigma \tau \rho \alpha \tau \varepsilon v o \mu \varepsilon v o v$ Present Participle (berjuang melawan dan menjadi tawanan) yang dapat disimpulkan bahwa perjuangan atau konflik yang dihadapi oleh Paulus berlangsung terus sejak waktu lampau sampai kini, yaitu pada saat Paulus berbicara. Jadi, jelaslah bahwa ayat-ayat ini menggambarkan suatu karakteristik konflik batin dari seorang Kristen sejati, sebuah konflik yang hanya mungkin ada di dalam diri manusia, di dalam siapa Roh Kudus bertindak secara aktif dan memiliki pikiran yang diperbaharui di bawah kendali Injil. Semakin manusia tersebut diperbaharui oleh Roh Allah, maka manusia akan semakin peka terhadap kuasa dosa yang terus-menerus ada dalam kehidupannya, serta adanya fakta bahwa ia masih dikuasai oleh sifat egoisme yang terus mengakar di dalam dirinya. 


\section{Kelepasan}

Ayat 24 merupakan ekspresi puncak dari konflik yang dinyataan dalam bagian sebelumnya di mana Paulus mempunyai kehendak yang baik tetapi tidak melaukannya oleh sebab prinsip dosa yang diam di dalam dirinya (ay 14-23). Dalam bagian ini terdapat seruan Paulus: "aku manusia celaka!” Ada yang berpendapat (pandangan yang mengatakan bahwa Paulus belum bertobat) bahwa bagian ini bukanlah merupakan ungkapan Paulus mengenai dirinya apalagi ungkapan dari orang yang percaya, tetapi pernyataan Paulus ini dapat dipahami dari konflik hidup orang percaya di mana di satu pihak ia masih hidup di dalam daging, tetapi di lain pihak ia berada di dalam Kristus. Di dalam daging berarti berada dalam tubuh kematian.

Selanjutnya Paulus bertanya: "Siapakah yang melepaskan aku dari tubuh maut ini?" "melepaskan" $\rho v \sigma \varepsilon \tau \alpha$ (rusetai) di sini memakai bentuk future yang berarti menunjukkan pembebasan di masa yang akan datang. Tubuh maut di sini adalah sama dengan tubuh kematian. Dalam konteks ini menunjukkan tubuh secara fisik. Tetapi tubuh kematian di sini tidak hanya mengacu pada tubuh secara fisik, karena dosa dan kematian tidak dapat dipisahkan, melainkan mengacu pada tubuh di mana di dalamnya ada dosa dan juga kematian tubuh secara rohani. Tubuh inilah yang perlu dilepaskan.

Pertanyaan yang diajukan Paulus di sini harus dipahami sebagai ekspresinya yang telah sangat menantikan sesuatu yang diketahuinya pasti akan datang. Cranfield menyatakan bahwa seruan ini menyatakan kesusahan yang amat dalam, tetapi tidak menyatakan suatu seruan keputusasaan atau tanpa harapan (Cranfield,1979).

Ayat 25 memberikan jawaban langsung dari pertayaan di ayat sebelumnya: "Syukur kepada Allah! oleh Yesus Kristus Tuhan kita." Pernyataan ini merupakan pernyataan kemenangan yang diberikan melalui Yesus Kristus (Morris, 1988). Kemenangan di sini adalah kemenangan dalam menghadapi kuasa dosa dan kematian. Memang perkataan Paulus mengekspresikan ucapan syukur atas pembebasannya sekarang, tetapi pembebasan di sini lebih condong memiliki signifikasi eskatologi (bnd. seruan pembebasan pada ayat sebelumnya yang menggunakan bentuk future). Pembebasan memang sudah dialami orang percaya sekarang, tetapi baru sebagian dan belum lengkap (Morris, 1988). Pembebasan atas tubuh kematian dan dosa ini secara penuh nantinya akan berlaku pada kebangkitan tubuh (Rm 6:5, 8; 8:10-11).

Pada ayat 26 yang merupakan bagian penutup (Morris, 1988), Paulus kembali kepada hidup yang sekarang, yaitu bentuk kata kini: "dengan akal budiku aku melayani hukum Allah dan dengan tubuh insaniku aku melayani hukum dosa." Ayat ini 
menimbulkan kesan hidup orang yang belum di dalam Kristus atau keadaan hidup yang lama, sehingga menimbulkan kesulitan untuk memahami transisi antara ayat sebelumnya yaitu ayat 25 dengan ayat 26 yang menggambarkan tentang pembebasan. Ada sebagian para ahli yang tidak menerima hal ini, karena bagian ini dianggap mengganggu atau mengacaukan sehingga mereka mengusulkan untuk membuang bagian ini.

Perlu untuk diperhatikan bahwa dalam bagian ini, Paulus sedang berbicara dalam konteks hidup orang yang sudah percaya. Sambil menantikan pembebasan terakhir itu, Paulus tetap berada dalam situasi yang simultan: dia ada di dalam Kristus tetapi dia juga berada di dalam sifat daging. Digambarkan di sini aku melayani Allah dengan akal budi yang sudah dibaharui, tetapi aku masih melanjutkan melayani hukum dosa dengan daging. Hal ini menunjukkan suatu dimensi dari keberadaan orang percaya yang belum mengalami kebangkitan tubuh.

Duun mengatakan tentang bagian ini, "The balance of verse $25 \mathrm{~b}$ therefore is not an expression of salvation still to begin but of the proccess of salvation underway and still to be completed. (Keseimbangan ayat 25b karena itu bukanlah suatu ungkapan keselamatan tetapi proses keselamatan yang sedang berlangsung untuk melengkapi) (Dunn,1985). Seorang ahli bernama Kasemann berpendapat bahwa dia mengakui penerimaan ayat 26 ini sebagai bagian yang asli dari keseluruhan interpretasi, tidak hanya dari konteks tetapi juga dari pandangan Paulus tentang baptisan, hukum dan pembenaran (Dunn,1985). Jadi, pada dasarnya tidak perlu terlalu mengkuatirkan masalah keaslian dari urutan atau pembagian ayat ini.

\section{KESIMPULAN DAN SARAN}

Hukum Taurat diberikan bukan untuk memberikan keselamatan, tetapi pengetahuan akan dosa. Hukum ini memperlihatkan dan menonjolkan pelanggaran dari setiap orang, pertama-tama orang Israel. Melalui hukum Taurat, bangsa Israel hendak diajar bahwa mereka sungguh-sungguh memerlukan pembenaran. Di sini Paulus membuat suatu pernyataan theologia yang sangat fundamental bahwa pembenaran tidak datang melalui hukum, melainkan melalui pembenaran oleh Allah. Pembenaran ini datangnya melalui iman kepada Yesus Kristus. Pembenaran di dalam Yesus Kristus adalah pembenaran yang sempurna, lengkap dan cukup bagi setiap orang percaya. Pembenaran adalah tindakan yuridis Allah di mana Ia menetapkan, berdasarkan kebenaran Tuhan Yesus Kristus, bahwa semua tuntutan hukum sudah dipenuhi bagi orang berdosa. Dengan dasar inilah orang percaya dibebaskan dari hukum. 
Ayat 14-23 secara nyata menggambarkan konflik dalam kehidupan orang percaya. Kendati sudah mengalami pembenaran, hidup orang percaya tidaklah dapat dijamin sempurna, bebas dari dosa dan sifat kedagingan. Dalam penantian pembebasan dari keberdiaman dosa dalam dirinya, orang percaya masih mengalami konflik antara naturnya yang sudah dibaharui dengan natur dosa dalam dirinya, yang menjadi subyek dari kuasa dosa sampai kebangkitan. Dalam hal ini pengudusan mutlak dialami oleh setiap orang yang sudah dibenarkan oleh Allah. Pengudusan adalah tindakan Roh Kudus yang penuh kasih karunia dan terus-menerus, yang olehnya Ia membebaskan orang berdosa yang sudah dibenarkan dari kecemaran karena dosa, memperbaharui keseluruhan naturnya dalam gambar dan rupa Allah, dan memampukannya melakukan perbuatan baik.

Cranfield menyimpulkan di bagian ini bahwa ayat 24-26 kembali menyatakan perjuangan melawan keinginan dosa (tetapi bukan menyatakan keputusasaan), penantian terhadap pembebasan terakhir dari tubuh, keyakinan ucapan syukur kepada Allah, komitmen kepada hukum Allah dan pengakuan yang jujur tentang fakta dari sifat keberdosaan. Aspek-aspek inilah yang akan mengalami pengudusan tersebut, sebab pembenaran yang dilakukan Allah terjadi di luar diri orang percaya dan tidak mengubah kehidupan batiniahnya sedangkan penyucian terjadi di dalam diri manusia dan semakin lama semakin mempengaruhi keseluruhan keberadaan orang itu. Selanjutnya, Ayat 2426 adalah kesimpulan dari ayat 14-23. Kesimpulan yang Paulus paparkan tidak hanya sebagai pendukung dari apa yang dinyatakan dalam ayat 13 tetapi juga sebagaimana yang dikatakan Crafield, sebagai kontribusi bagi suatu elemen dari gambaran hidup yang dijanjikan bagi orang yang dibenarkan oleh iman. Hidup yang dibicarakan di sini adalah berkaitan dengan fakta bahwa Kristus membebaskan orang percaya, yakni dari sisa ikatan dosa yang telah berakar (ay 14 dan 23) dan dari kerusakan jasmani serta kematian, tidak hanya pada masa sekarang ini tetapi juga dari perspektif eskatologi.

\section{DAFTAR PUSTAKA}

. (2008) Paulus dan Diri. Surabaya: Momentum. . (2002)._Alkitab. Jakarta: Lembaga Alkitab Indonesia.

- (1989). Webster Encyclopedic Unabridged Dictonary of the English Language. New York: Potland House.

Barret, C. K. (1957). A Comentary on the Epistle to The Romans. HNCT. San Fransisco: Harper and Row. 
Bauer, Walter. (1979). A Greek English Lexicon of the New Testament and Other Early Christian Literature, trans. German ed. by W. F Arndt and F. W. Gingrich. Chicago: The University of Chicago Press.

Calvin, Jhn. (1844). Commentary upon the Epistle to the Romans. Diedit oleh Henry Beveridge. Edinburgh: Calvin Translation Society.

Chamblin, J. K.(1993). Psikologi, Dictionary of Paul and His Letters, ed. Gerald Hawthorne \& Ralph Martin. Downers Grove: Inter-Varsity Press.

Cranfield, C. E. B. (1979). A Critical and Exegetical Commentary on The Epistle to The Romans. ICC. Edinburgh: T\&T Clark.

Childs, B. S. (1985). The New Testament As Canon And Introduction. Philadelphia: Fortress Press.

Dunn, James D. G. (1985), "Spirit" The New International Dictionary of New Testament Theology vol. III. ed. Colin Brown. Grand Rapids: Zondervan Publishing House.

Gundry, R. H. (1980), The Moral Frustration of Paul Before His Conversion: Sexual Lust in Romans 7:7-25. In Pauline Studies, FS F.F. Bruce, ed. D. A. Hagner et all. Exeter: Paternoster.

Lambrecht, J. (1974). Man Before and With Out Christ: Roma 7and Pauline Anthropology. Lovain Studies.

Luther's Works. (1972), vol. 25: Lectures on Romans, edited by Hilton C. Oswald. St. Louis: Concordia Publishing House.

Moo, Douglas. J.(1996). The Epistle to The Romans. NICNT. Grand Rapids: Eerdmans. Morris, Leon. (1988). The Epistle to The Romans. PNTC. Grand Rapids: Eerdmans. Murray, John. (1959). The Epistle to The Romans. NICNT. Grand Rapids: Eerdmans. Mounce, William D. (1993). The Analitical Lexicon to the Greek New Testament. Grand Rapids: Zondervan Publishing House.

Myres, Yancey Carlos. (1959). The New Testament Doctrine of the Mind. Th.M. thesis, Dallas Theological Seminary.

Ridderbos, H. (2008). Paulus Pemikiran Utama dan Theologinya. Surabaya: Penerbit Momentum.

Witmer, John A. (1988). "Romans” The Bible Knowledge Commentary ed. John F. Walvoord \& Roy B Zuck. Wheaton: Victor Books.

Wuest, Kenneth S. (1992), "Romans" Wuest Word Studies From the Greek New Testament, vol. I. Grand Rapids: Eerdmans Publishing Company. 